\title{
FILM ISLAMI SEBAGAI MODEL INTERPRETASI ATAS AL-QUR'AN DAN HADIS: Kasus Film Ayat Tentang Cinta
}

\author{
Mila Aulia, ${ }^{1}$ Miski $^{2}$ \\ 1Universitas Islam Negeri Maulana Malik Ibrahim Malang \\ 2Universitas Islam Negeri Maulana Malik Ibrahim Malang \\ Email: ${ }^{1}$ miaumilaaulia@gmail.com; 2miski@uin-malang.ac.id
}

\begin{abstract}
This paper analyzes the movie Ayat tentang Cinta, which still has not received much attention from the researchers, namely from the aspect of the existence of the Qur'anic verses and traditions in it. Two core questions want to be the focus of the study, first, how does the movie Ayat tentang Cinta position the Qur'an [and hadith] as a representation of an interpretation of the Qur'an and hadith? Secondly, how is the existence of the values of the Qur'an [and hadith] in the film being one of the concourses of righteousness? This paper is a qualitative study, using content analysis and a semiotic approach. The results of this study show that in the movie Ayat tentang Cinta, it appears how the scenes displayed by the actors can show the relevant point of a movie as an interpretation of the Qur'an and Hadith, for example, the cafeteria in marriage is allegedly based on the QS. Al-Nur: 26. Secondly, in the movie Ayat tentang Cinta, many of the values of the Qur'an and Hadith in its diverse form, such as how each central figure in the movie describes the things that are relevant to the values of the Qur'an and hadith, at least through the distinctive scenes. All of this, as well as being one of the interesting facts about the construction efforts of righteousness by actors into the minds of audiences. Of course, in typical terminology.
\end{abstract}

Keywords: Film Islami, Ayat Cinta, Living al-Qur'an, Semiotika, Film Religi.

\section{A. Pendahuluan}

Film merupakan salah satu sarana hiburan yang banyak dipilih oleh masyarakat dengan motif yang beragam mengapa film menjadi pilihan populer. Mulai dari hanya sebatas hiburan, mengikuti tren tertentu, ramai dibicarakan karena mengandung unsur kontroversi, sampai mencari hikmah dibalik adanya film tersebut. ${ }^{1}$ Antara sineas dan penonton, keduanya sama-sama memiliki tantangan antara menciptakan film yang berbobot dan selektif dalam memilih

1 Miski Mudin, Islam Virtual, Diskursus Hadis, Otoritas, Dan Dinamika Keislaman Di Media Sosial, ed. Nurul Afifah, 1st ed. (Yogyakarta: BILDUNG, 2019). 
film yang layak untuk ditonton. Salah satu cara yang dapat digunakan untuk mengeksplisitkan nilai implisit dalam suatu film adalah dengan menggunakan semiotika. Salah satu tokoh semiotika yang teorinya dinilai relevan digunakan untuk menganalisis film adalah teori milik Charles Sander Pierce. Analisis film menggunakan pendekatan semiotika sangat menarik untuk dilakukan karena akan menonjolkan nilai film secara lebih mendalam, melebihi pemahaman penonton pada umumnya. ${ }^{2}$

Lebih dari itu, banyak juga penelitian yang lebih khusus mengarahkan objek penelitiannya pada film-film religi dengan pendekatan semiotika dengan tujuan merepresentasikan nilai-nilai tertentu dalam ranah keislaman. ${ }^{3}$ Sebagian kajian membahas tentang konstruksi kesalehan melalui dialog dan adegan yang terdapat dalam film. ${ }^{4}$ Beberapa diantaranya membahas dakwah dalam film Indonesia. ${ }^{5}$ Hasil penelitian-penelitian tersebut menarik untuk dikupas lebih lanjut dikarenakan pengkaji terdahulu sebatas membahas bagaimana mengaplikasikan teori dari tokoh semiotika ke dalam suatu film, kemudian mentipologikan hasil semiotika yang diperoleh dari film tersebut menjadi pemahaman yang masih bersifat umum. Walaupun dalam kajian tertentu yang obyeknya berupa film religi, implikasi semiotika masih berada di ranah sosiokultural dan humanisme, karena kebanyakan pengkaji terdahulu memiliki bidang keilmuan berbasis komunikasi, sosial budaya, dan humaniora. Di samping itu, panjangnya durasi film menyebabkan analis semiotika tidak berjalan secara

${ }^{2}$ Ahmad Toni and Rafki Fachrizal, "Studi Semitoka Pierce Pada Film Dokumenter The Look of Silence: Senyap," Jurnal Komunikasi 11, no. 2 (2017): 137-54, doi:10.20885/komunikasi.vol11.iss2.art3.

3 Alga Lilis et al., "Analisis Semiotika Film Christian Metz : Studi Kasus Visualisasi Pesan,” Publika Budaya 5, no. 1 (2017): 21-27; Syaiful Qadar Basri, "Film 99 Cahaya Di Langit Eropa Yang Merepresentasikan Film As Social Practice Bagi Wanita Muslimah," Studi Islam 15 (2019): 58-74; Jalaluddin and Nabilla Putri Syarifa, "Represenasi Citra Positif Islam Dalam Film Kingdom of Heaven," LP3M 4 (2018): 122-31; Nur Fatimah, "Membingkai Ajaran Islam Dengan Produk Multimedia Hakikat Kaya Dalam Film Dokumenter Religi 'Bukan Seperti Miskin Tidak Seperti Kaya,'” Jurnal Ilmu Dakwah 36, no. 2 (2016): 211-28.

4 Zahrotus Sa'idah, "Konstruksi Kesalehan Dalam Film Cinta Suci Zahrana (Antara Identitas, Modernitas Dan Komodifikasi Agama)," Thesis (2017): 1-112.

${ }^{5}$ Masturina Khoirun Nisa, Ucik Ana Fardila, and Agus Widodo, "Isi Pesan Dakwah Aqidah Dan Syariah Dalam Film Indonesia Islami 'Jilbab Traveler Love Sparks In Korea' (Kajian Semiotik Pada Film Islami Indonesia)," Translitera 8 (2019): 1-12; Tika Kania Nurazizah, Saeful Anwar, and Bahrudin Bahrudin, "Pesan Dakwah Pada Media Sosial," Tabligh: Jurnal Komunikasi Dan Penyiaran Islam 3, no. 3 (2020): 275-91, doi:10.15575/tabligh.v3i3.699; M Ali Musyafak, "Film Religi Sebagai Media Dakwah Islam," Jurnal Islamic Review II, no. 2 (2013): 327-38. 
komprehensif, sehingga masih banyak bagian yang tercecer yang tidak disebutkan dalam artikel maupun jurnal.

Ayat tentang Cinta adalah salah satu film pendek islami yang banyak mendapatkan respon positif dari para penontonnya. Sebagai bagian yang tidak terpisahkan dari aspek semiotis yang menyertai, terdapat hal yang seringkali luput dari kajian-kajian sebelumnya, baik dalam koteksnya yang umum, seperti kajian terhadap film islami pada umumnya, maupun dalam konteksnya yang khusus yakni terhadap film ini. Aspek tersebut adalah keberaadaan al-Qur'an dan hadis di dalamnya. Padahal, judul "Ayat tentang Cinta" sejak awal diasosiasikan dengan ayat al-Qur'an secara literalistik dan denotatif, bukan dalam terminologinya yang metaforis. Hal ini ditandai dengan kenyataan bahwa pada sken pembuka saja, salah satu pemeran utama: Anwar, melafalkan QS. al-Nur: 26, yang kemudian secara keseluruhan, plot dalam film ini tidak jauh dari terma ayat tersebut yakni tentang kesetaraan (kafaah) dan sebagainya, termasuk pula keberadaan hadis Nabi yang mudah dijumpai di dalamnya.

Berpijak pada paparan di atas, kajian ini hendak menjawab dua pertanyaan inti, yaitu: pertama, bagaimana film Ayat tentang Cinta memosisikan al-Qur'an [dan hadis] hingga ia tanpa sebagai representasi dari sebuah tafsir dan syarah? Kedua, bagaimana pula keberadaan nilai-nila al-Qur'an [dan hadis] dalam film tersebut menjadi salah satu konstruk dari kesalehan? Jawaban atas dua pertanyaan ini dapat menciptakan kesadaran dalam benak penonton untuk tidak hanya menjadikan dirinya sebagai penikmat hiburan semata melainkan dapat lebih kritis dan peka dalam menilai pesan-pesan yang terkandung dalam karya apapun berupa audiovisual. Lebih jauh dari itu, adanya penelitian ini dapat memberikan referensi kajian ilmiah bagi peneliti yang ingin membahas topik ini secara lebih lanjut.

Sebagai langkah konkrit dari tujuan tersebut, pada penelitian ini, penulis menggunakan pendekatan kebahasaan dan tafsir al-Qur'an. Jika dilihat dari jenisnya, penelitian ini termasuk penelitian kualitatif dengan harapan agar designnya dapat berkembang selama proses penelitian berlangsung. Sedangkan alat yang digunakan untuk memperoleh hasil yang diinginkan adalah dengan menggunakan pendekatan semiotika milik Charles Sander Pierce. Sumber data primer pada penelitian ini adalah film pendek Ayat Tentang Cinta itu sendiri berupa video YouTube yang diperoleh dari akun bernama Film Maker Muslim. Adapun sumber data sekundernya berasal dari informasi sosial media melalui 
postingan di Instagram, literatur-literatur kajian ilmiah, serta buku-buku pendukung. Dalam teknik pengumpulan data, penulis akan melakukan observasi atau pengamatan terkait beberapa hal di balik layar yang berhubungan dengan film Ayat Tentang Cinta, kemudian menggunakan kajian dokumen sebagaimana yang telah disebutkan dalam sumber data primer dan sekunder. Setelah melakukan pengumpulan data, maka metode penelitian yang dilakukan setelahnya adalah teknik pengolahan data dengan melakukan beberapa tahapan, yaitu : 1) analisis semiotik perspektif Charles Sander Pierce $^{6}$ sehingga menghasilkan tipologi pembahasan berupa ikon, indeks dan simbol, 2) analisis tema kurtural; memahami gejala khas dari analisis sebelumnya, sehingga dapat menemukan hubungan yang terdapat dalam nilai yang muncul dari tanda-tanda yang telah dianalisis menjadi satu kesatuan pemahaman yang holistik, dalam hal ini melahirkan nilai qurani sebagai konstruksi kesalehan, 3) kesimpulan, maksudnya menyimpulkan hasil penelitian dari analisa yang telah dilakukan serta memverifikasinya.

\section{B. Teks, Film dan Teori Semiotika: Mengurai Titik Relevansi}

Film merupakan salah satu media massa yang sering digunakan masyarakat dalam mengonsumsi paradigma instan yang sudah diolah menjadi sebuah karya, khususnya para generasi milenial yang hampir setiap waktu tidak lepas menggunakan media sosial dalam kehidupan sehari-hari. Bahkan film bertajuk Islam bisa mengembangkan identitas pemuda Indonesia di luar orang tua, pendidikan formal dan pergaulan. ${ }^{7}$ Maka, jika diperhatikan dari sudut pandang sosial, pantas al-Qur'an dan hadis juga disebut sebagai media massa yang secara global dipahami oleh seluruh lapisan masyarakat bahwa dia adalah satu kitab suci yang kedudukannya diagungkan dan tidak diperkenankan sembarangan dalam memposisikannya. Sedangkan bentuk dari media massa sendiri bermacam-macam dan terus mengalami perkembangan, mulai dari

\footnotetext{
${ }^{6}$ Wahjuwibowo and Indawan Seto, Semiotika Komunikasi Edisi III: Aplikasi Praktis Untuk Penelitian Dan Skripsi Komunikasi, 2019.

${ }^{7}$ Hariyadi, "Finding Islam in Cinema: Islamic Films and the Identity of Indonesian Muslim Youths," Al-Jami'ah: Journal of Islamic Studies 51, no. 2 (2013): 443-73, doi:10.14421/ajis.2013.512.443-473; "Islamic Films And Identity: The Case Of Indonesian Muslim Youths," n.d.; Muhammad Wahyuda, "Peran Film Ayat-Ayat Cinta 2 Terhadap Prilaku Etika Islam Pada Remaja," Syifa Al-Qulub 22 (2018): 31-40; Robby Aditya Putra, "Dampak Film Para Pencari Tuhan Jilid X Terhadap Religiusitas Remaja," Jurnal Dakwah Dan Komunikasi 3, no. 1 (2018): 1-24.
} 
media paling kuno tetapi penggunaannya tetap eksis sampai sekarang yang disebut sebagai media cetak, kemudian media elektronik, sampai media interet, yang mana semuanya mempunyai keterkaitan yang erat antara satu dengan yang lain. ${ }^{8}$

Oleh karena itu, al-Qur'an dan hadis pun dapat dikategorikan sebagai salah satu bentuk dari media massa karena sumber al-Qur'an yang ada hingga saat ini berasal dari mushaf berupa lembaran-lembaran yang disatukan menjadi sebuah kitab. Hadis pun punya titik genealogi berupa catatan-catatan para ulama dari hasil perjalanan panjang mereka melacak informasi yang ditengarai bersumber dari Nabi. Hal tersebut menunjukkan bahwa al-Qur'an dan hadis memiliki kelengketan dengan buku sebagai salah satu media massa berupa media cetak ${ }^{9}$ Perkara al-Qur'an dan hadis yang berada dalam suatu film merupakan sumber dari sesuatu yang bersifat visual (media cetak) kemudian di-audiovisualkan melalui adegan yang ditampilkan dalam film. Sehingga, dengan menonjolkan nilai al-Qur'an dan hadis dalam film berarti sama dengan menerapkan karakter dari media massa itu sendiri yang bersifat mengajak dan mempengaruhi, sekaligus dapat menjadi proses komunikasi Ilahi kepada manusia sebagai media komunikasi dan disampaikan kepada khalayak.

Apabila titik temu al-Qur'an dan hadis sebagai media massa telah diperoleh, maka selanjutnya adalah spesifikasi media massa dalam mencapai tujuannya berupa pemberian pengaruh kepada penonton yang tersampaikan melalui pesan yang telah diolah dalam bentuk kemasan komunikasi massa secara utuh. Film pendek berjudul Ayat Tentang Cinta terklasifikasi sebagai film ber-

8 Miski, "Fenomena Meme Hadis Celana Cingkrang Dalam Media Sosial," Harmoni 16, no. 2 (2017): 291-306; Miski, "Komikisasi Hadis: Arah Baru Syarah Hadis Di Indonesia Studi Kritis Atas 99 Pesan Nabi: Komik Hadis Bukhari-Muslim,” Millati: Journal of Islamic Studies and Humanities 2, no. 1 (2017): 125-44, doi:10.18326/mlt.v2i1.125-144; Miski Mudin, ISLAM VIRTUAL, Diskursus Hadis, Otoritas, Dan Dinamika Keislaman Di Media Sosial, ed. Nurul Afifah, 1st ed. (Yogyakarta: BILDUNG, 2019); Nafisatuzzahro', 'Tafsir Al-Qur'an Audiovisual Di Cybermedia: Kajian Terhadap Kajian Al-Qur'an Di Youtube Dan Implikasinya Terhadap Studi Al-Qur'an Dan Tafsir" (UIN Sunan Kalijaga, 2016); Ali Hamdan and Miski, "Dimensi Sosial Dalam Wacana Tafsir Audiovisual," Religia 22, no. 2 (2019): 248-66; Saifuddin Zuhri, Moh Hidayat Noor, and Miski, "Komunitas Online Www.arrahmah.com Serta Seruan Kembali Pada Al-Quran Dan Hadis: Identitas, Ideologi, Dan Imaji Fundamentalisme," in Ancoms: 2nd Annual Conference for Muslim Sholars, 2018, 144-60.

9 Moh Zahid, "Posisi Dan Fungsi Mushhaf Al-Qur'an Dalam Komunikasi Massa," Nuansa 11, no. 1 (2014): 77-106. 
genre islami, dari kata kunci islami saja dapat melahirkan pembahasan yang melebar tentang arah pembahasan yang akan diambil. Jika diidentifikasi dari komponen-komponen yang menyusun film Ayat Tentang Cinta seperti latar pembuatan film, tokoh-tokoh, skenario, properti, keseluruhan alur dan adegan, maka dapat dengan mudah disimpulkan bahwa film ini memiliki orientasi di ranah dakwah.

Dewasa kini, dakwah tidak melulu tentang seorang muballigh yang menyampaikan pesan bernilai keagamaan kepada jamaahnya dalam suatu majelis tertentu. Munculnya era cyber sudah selayaknya dipandang sebagai peluang sekaligus tantangan guna mewujudkan dakwah Islam yang lebih efektif, efisien dan mengglobal. ${ }^{10}$ Salah satunya adalah dengan menyelipkan dakwah melalui film yang disebarkan lewat jejaring sosial, dalam penelitian ini menggunakan Youtube. Disamping itu, film bisa menjadi media dakwah anti kekerasan. ${ }^{11}$ Dengan begitu, para pelaku dakwah telah menyikapi perkembangan teknologi komunikasi secara proaktif di era cyber yang eksistensinya dapat diketahui oleh masyarakat dunia. Sehingga komunitas FMM Film Maker Muslim dinilai berhasil mewujudkan orientasi dakwahnya dengan menonjolkan nilai-nilai qurani melalui salah satu produksi film pendek berujudul Ayat Tentang Cinta.

Lebih dari itu, respon penonton berupa komentar-komentar positif yang jauh lebih banyak dari pada komentar negatifnya menunjukkan bahwa FMM sukses membidik sasaran penonton secara tepat. Melalui data fakta dari kolom komentar film Ayat Tentang Cinta, dapat disimpulkan bahwa mayoritas penonton adalah penganut agama Islam dengan tipikal sedang mendalami ajaran Islam melalui hikmah dibalik suatu kejadian. Hal ini terbukti dari nada komentar para penonton yang seolah-olah merepresentasikan pemahaman utuh atas pesan alQur'an dan hadis yang tersampaikan melalui film. Jadi, dalam konteks ini posisi alQur'an dan hadis dalam film Ayat Tentang Cinta adalah sebagai objek utama film, karena nuansa al-Qur'an yang dimunculkan dari scene pertama hingga terakhir melahirkan inti pesan al-Qur'an dan hadis di benak audien, meski pun yang tampak dominan memang pesan al-Qur'an.

\footnotetext{
${ }^{10}$ Nurazizah, Anwar, and Bahrudin, "Pesan Dakwah Pada Media Sosial."

${ }_{11}$ Primi Rohimi, "Keragaman Islam Dalam Film Indonesia," Jurnal Dakwah 16, no. 2 (2015): 291-304.
} 
Penelitian ini akan mengkaji bagaimana film pendek Ayat Tentang Cinta mengkonstruksikan kesalehan melalui adegan dan dialog yang merepresentasikan nilai-nilai qurani. Akan tetapi tidaklah mudah untuk menyampaikan konstruksi kesalehan dalam suatu film walaupun film tersebut adalah film religi, karena sejatinya film merupakan alat dagang yang bertujuan mendapat respon positif dari konsumen. Oleh karena itu, tahap awal yang harus dilaksanakan adalah mengkaji latar belakang pembuatan film melalui informasi yang telah diperoleh. Selanjutnya, untuk masuk ke dalam fokus kajian ini maka akan dibahas trikotomi teori semiotika Charles Sander Pierce, meliputi ikon, indeks dan simbol. Ketiga unsur tersebut merupakan tanda yang digunakan untuk memahami makna, karena Pierce memandang tanda bukan sebagai sebuah struktur belaka, melainkan merupakan bagian dari proses pemahaman. ${ }^{12}$ Penjelasannya rincinya sebagai berikut:

Pertama, ikon. Ikon merupakan suatu tanda yang menggambarkan ciri sehingga eksistensi suatu benda itu ada. Dengan kata lain, ikon adalah dimensi fisik yang menyerupai apa yang dimaksudkan. Setiap scene dalam film Ayat Tentang Cinta pasti merepresentasikan suatu pemahaman bagi penonton melalui ciri yang dikeluarkan berupa ikon-ikon tertentu. Kedua, indeks. Indeks adalah tanda yang memiliki hubungan kausalitas dengan apa yang direpresentasikannya, singkatnya indeks merupakan bukti dari terjadinya sesuatu. Buktibuktiyang muncul dalam adegan dan dialog pada film Ayat Tentang Cinta menjadi suatu tanda yang mencerminkan adanya indeks dalam film melalui sebab-akibat yang diperankan.

Ketiga, simbol. Simbol dapat disebut sebagai inti dari dua teori semiotika sebelumnya, karena simbol merupakan tanda yang lahir atas kesepakatan yang telah dipahami bersama berdasarkan pengetahuan umum sebelumnya. Maknamakna yang muncul dalam film Ayat Tentang Cinta menjadi simbol melalui plotplot yang tersusun dalam film, yang mana hal tersebut sudah disepakati maksudnya berdasarkan pengetahuan yang dimiliki oleh penonton. Apabila trikotomi semiotika di atas telah dilewati secara menyeluruh, maka pemaknaan sesuatu secara utuh dapat termanifestasikan dengan baik. Setelah menganalisis film menggunakan trikotomi teori semiotika Charles Sander Pierce, maka tahap selanjutnya adalah pemaparan konstruksi kesalehan yang dicerminkan melalui

12 Yayan Rahtikawati and Dadan Rusmana, Metodologi Tafsir Al-Qur'an, 2013. 
nilai-nilai qurani yang ditunjukkan melalui adegan dan dialog dalam film pendek berjudul Ayat Tentang Cinta.

\section{Film Ayat Tentang Cinta: Pengenal Umum}

Film berujudul Ayat Tentang Cinta merupakan salah satu film pendekyang diproduksi oleh suatu komunitas bernama Film Muslim Maker atau dikenal dengan sebutan FMM. Motif FMM memproduksi bermacam-macam film pendek berbasis religi adalah sebagai sarana untuk berdakwah dan menebar inspirasi. FMM menggunakan YouTube sebagai lapangan utama penyebaran dakwahnya, yang mana perilisan film pertama sudah dimulai sejak 14 September 2014 dan sampai saat ini (Maret 2020) telah memiliki 616.000 subscribers. Selebihnya, FMM juga memanfaatkan instagram, website, e-mail, facebook, line dan twitter sebagai media sekunder untuk lebih jauh mengembangkan sekaligus mengenalkan karya-karya film yang diproduksi kepada masyarakat.

Adapun film Ayat Tentang Cinta dipublikasikan pada 20 Desember 2019 dan telah ditonton sebayak 166.830 kali (terhitung dari tiga bulan yang lalu) dengan 6.600 like, 49 dislike dan 346 komentar. Durasi film pendek ini selama sembilan belas menit lebih delapan detik. Pemeran utama dalam film ini diperankan oleh tiga orang, antara lain Zaid Fahd sebagai Anwar, Muhammad Iqbal sebagai Haydar dan Fajarina al-Kautsar sebagai Fatimah, sedangkan pemeran figuran meliputi Abi Anwar, Umi Anwar, Abah Fatimah, Ambu Fatimah, jamaah salat dan rekan - rekan majelis Anwar. Film Ayat Tentang Cinta ini disutradarai oleh M. Amrul Ummami.

Ayat Tentang Cinta adalah film pendek mengenai Anwar yang akan melamar Fatimah namun ada Haydar yang juga melamar, sehingga mengharuskan abah Fatimah memberikan ujian kepada mereka berdua untuk mencari ayat tentang cinta. Video dimulai dengan ucapan terimakasih sekaligus promosi film secara singkat yang dibawakan oleh Muhammad Iqbal. Kemudian dilanjutkan oleh adegan pertama dimana Anwar melantunkan ayat suci al-Qur'an Surat an-Nur ayat 26 di sebuah surau kecil. Selepas itu dia menuju rumahnya untuk menyampaikan kemantapan hatinya melamar Fatimah az-Zahra kepada kedua orang tuanya dan tidak lupa meminta doa restu kepada keduanya.

Sesampainya di rumah Fatimah, Anwar bertemu dengan seorang laki-laki yang belum dia kenal sebelumnya. Laki-laki tersebut bernama Haydar. Kedua 
orang tua Anwar dan Haydar pun sebelumnya telah megenal baik keluarga Fatimah sehingga bukan sesuatu yang aneh jika Anwar dan Haydar menyampaikan salam dari orang tua masing-masing. Anwar dan Haydar belum saling mengetahui niat mereka pada hari itu yang sama-sama berkeinginan melamar Fatimah, bahkan Abah dan Ambu Fatimah pun baru mengetahuinya di hari yang sama. Dalam situasi yang kurang mengenakkan ini, Abah Fatimah memanggil anaknya untuk menanyakan secara langsung pria mana yang lebih condong dijadikan pilihan sebagai calon imamnya kelak. Akan tetapi Fatimah bingung memilih siapa karena dia belum pernah merasakan jatuh cinta, sehingga Fatimah meyerahkan mutlak urusan tersebut kepada orang tuanya. Di tengah kondisi yang membingungkan, Abah Fatimah memutuskan mereka untuk kembali lagi minggu depan di waktu yang sama dengan sudah membawa satu ayat dalam al-Qur'an yang dianggap sebagai ayat tentang cinta sekaligus menceritakannya kepada kedua orang tua Fatimah di hadapan Fatimah secara langsung.

Kemudian mereka pulang ke rumah masing-masing, pada adegan setelahnya hanya Anwar yang digambarkan bagaimana proses ikhtiarnya dalam mencari satu ayat yang menjelaskan cinta dalam al-Qur'an selama satu minggu dengan segala bekal keilmuan agama yang dia miliki. Walaupun sebenarnya Anwar hampir putus asa karena tidak kunjung menemukan ayat tersebut, akhirnya dia ingat bahwa sebelum melamar Fatimah, Anwar membaca salah satu ayat dalam al-Qur'an yang terdapat dalam surat an-Nur ayat 26. Dengan itu Anwar menjadi sangat yakin bahwa ayat cinta merupakan Q.S an-Nur ayat 26, sehingga dia memutuskan ayat tersebut yang dipilih dan dijelaskan kepada keluarga Fatimah.

Hingga tiba pada satu minggu kemudian yang telah dinantikan, Anwar dan Haydar kembali berkumpul di kediaman Fatimah untuk menceritakan ayat cinta yang menjadi pilihan mereka. Dengan penuh percaya diri, Anwar meminta izin kepada Abah Fatimah untuk lebih dulu meyampaikan ayat pilihannya. Bagi Anwar, Q.S an-Nur merupakan ayat cinta yang menerangkan janji Allah untuk mempertemukan wanita yang baik pada laki-laki yang baik, membahas tentang bagaimana perempuan dan laki-laki harus memantaskan dirinya menjadi orang yang baik untuk mendapatkan pendamping hidup yang terbaik. Setelah Anwar menyampaikan argumentasinya, maka giliran Haydar menjelaskan ayat cinta yang menjadi pilihannya. Haydar memulainya dengan permohonan maaf karena 
selama satu minggu penuh mencari ayat tentang cinta, dia tidak menemukannya bahkan sampai hari itu sehingga dia merasa belum bisa membuktikan apa itu cinta. Menurut Haydar, semakin dia mencari semakin sulit dia menyimpulkan karena tidak ada satu ayat al-Qur'an pun yang tidak menunjukkan cinta Allah kepada makhluk-Nya. Haydar memohon maaf karena merasa belum pantas mendapatkan Fatimah dengan memenuhi syarat berupa satu pilihan ayat dalam al-Qur'an tentang cinta. Maka di akhir penjelasan Haydar, Fatimah mulai angkat bicara bahwa dia telah jatuh cinta. Fatimah telah menemukan makna cinta sesungguhnya dari penjelasan Haydar. Sehingga pilihan Fatimah jatuh kepada Haydar sebagai calon suaminya.

Dari kejadian yang dialami oleh Anwar, dia menjadi sadar bahwa hafalan al-Qur'an maupun ilmu keagamaan yang dimiliki seseorang tidak menjamin tercapainya keinginan seseorang jika tidak disertai dengan kemuliaan akhlak dan kerendahan hati, apalagi bila masih ada kesombongan dalam dirinya. Anwar memperoleh banyak pelajaran dari Haydar dan Fatimah agar menjadikan ilmu sebagai alasan untuk rendah hati, menjadikan akhlak sebagai satu-satunya penghias diri, serta mencintai dengan ikhlas tidak akan meninggalkan luka dan patah hatinya akan mendekatkan diri kepada Sang Pencipta. Seperti video-video yang diunggah di YouTube pada umumnya, film Ayat Tentang Cinta diakhiri dengan scene ucapan terimakasih telah menonton, permintaan like, komentar dan subscribe, serta promosi gamis yang dikenakan Fatimah selama film berlangsung.

Beralih pada respon penonton terhadap film pendek Ayat Tentang Cinta. Dengan menganalisis komentar para penonton, komentar positif berbanding jauh lebih banyak dari komentar negatifnya. Hal tersebut dapat dibuktikan dari adanya data berupa komentar yang terdapat di kolom komentar YouTube sebanyak 348 komentar (diakses pada 1 April 2020, pukul 23.06 WIB). Dari sekian banyak komentar, hanya ditemukan lima komentar yang menunjukkan adanya beberapa hal negatif dalam film, itupun hanya berupa kritik yang bersifat membangun. Tidak ditemukan komentar-komentar negatif seperti cemoohan, kata-kata tidak sopan, nyinyiran dan lain sebagainya. Selebihnya berupa komentar-komentar positif penonton yang sangat mendukung perilisan film ini. Adapun respon positif para penoton diantaranya berupa ungkapan-ungkapan terimakasih atas film yang mengispirasi, hikmah-hikmah yang diserap penonton kemudian ditulis dalam komentar dan kesan penoton atas alur cerita yang anti- 
mainstream sehingga menghasilkan akhir cerita yang tidak tertebak. Secara keseluruhan dapat dikatakan bahwa FMM sukses menembus pasar film, target penonton yang dituju sesuai sasaran dengan latar belakang FMM dalam menyampaikan dakwah dan inspirasi. Dengan demikian, FMM sesungguhnya tidak hanya mengusung idealisme dakwah, tetapi juga berkontribusi bagi pelanggengan budaya popular dengan komodifikasi agama sebagai perantara. ${ }^{13}$

\section{Film Ayat Tentang Cinta sebagai Tafsir al-Qur'an [dan Syarah Hadis]}

Scene pertama dalam film Ayat Tentang Cinta dimulai dengan lantunan Q.S. an-Nur ayat 26 oleh Anwar, dan sampai film berakhir pun ayat ini selalu disebut-sebut bahkan Anwar mengklaimnya sebagai ayat tentang cinta. Sehingga melalui rentetan cerita pada film, maka dapat dikatakan bahwa ikon al-Qur'an dalam film Ayat Tentang Cinta terletak pada surat an-Nur ayat 26. Dari beberapa kitab tafsir, disebutkan bahwa yang melatarbelakangi turunnya ayat ini adalah sebagai bentuk pembelaan oleh Allah secara langsung terhadap istri Rasulullah SAW, Aisyah r.a yang telah dituduh oleh kaum munafik bahwa dirinya telah melakukan perbuatan keji, yang mana tuduhan tersebut dilontarkan oleh Abdullah bin Ubay, sehingga Allah membebaskan Aisyah dari tuduhan munafik melalui ayat ini. At-Thabrani meriwayatkan dengan sanad yang para perawinya tsiqat dari Abdurrahman bin Zaid bin Aslam tentang firman-Nya, "Perempuanperempuan yang keji untuk laki-laki yang keji,.." bahwa ayat ini turun tentang Aisyah ketika difitnah orang munafik, lalu Allah menyatakan kebersihannya dari tuduhan itu. ${ }^{14}$

Jika ditinjau dari sudut pandang tafsir, surat an-Nur ayat 26 merupakan uraian penegasan dari ayat sebelumnya yaitu an-Nur ayat 3 yang menyatakan bahwa pezina tidak wajar menikah kecuali dengan lawan seksnya yang sesama pezina. Bila secara khusus ayat ini hanya ditujukan pada Aisyah, maka secara umum ayat ini juga ditujukan pada seluruh laki-laki dan wanita yang ada di muka bumi. Mengenai pengulangan kata al-khabitsat dan al-khabitsun dengan redaksi kebalikan dari kalimat sebelumnya berupa at-thayyibat dan at-thayyibun

13 Hakim Syah, "DAKWAH DALAM FILM ISLAM DI INDONESIA ( Antara Idealisme Dakwah Dan Komodifikasi Agama )” XIV, no. 2 (2013): 263-82. Lihat juga, Ropingi el Ishaq, "HIBURAN DAN DAKWAH: SEBUAH ERA BARU DAKWAH ISLAMIYAH," AT-TABSYIR 2, no. 1 (2014): 117-32.

14 Jalaluddin Al-Mahalli and Jalaluddin As-Suyuthi, Tafsir Jalalain; Lengkap Dan Disertai Asbabun Nuzul, 2017. 
bertujuan untuk menampik argumen yang berpendapat bahwa laki-laki yang bejat bisa saja menikah dengan perempuan yang baik, maka ayat tersebut mempertegas bahwa laki-laki yang bejat akhlaknya hanya pantas menjadi pasangan wanita yang bejat akhlaknya pula bukan wanita yang baik-baik, walaupun parameter kebejatan dan kebaikan seseorang tidak dapat diukur dari subjektif asumsi manusia. ${ }^{15}$

Menurut M. Quraish Shihab, surat an-Nur ayat 26 menegaskan salah satu hakikat ilmiah menyangkut hubungan kedekatan antara dua insan, khusunya kedekatan pria dan wanita atau suami dan istri. Jalinan hubungan antar keduanya harus bermula dari adanya kesamaan antara kedua belah pihak. Tanpa kesamaan itu, hubungan keduanya tidak akan langgeng. Maka, ada empat fase yang harus dilalui agar cinta antar-manusia mencapai puncaknya. Fase pertama, kedua belah pihak harus merasakan ada atau tidaknya kedekatan. Fase kedua, fase pengungkapan diri dimana masing-masing meraskan ketenangan dan rasa aman berbicara tentang seluk beluk dirinya. Fase ketiga, melahirkan saling ketergantungan sehingga bisa saling mengandalkan dalam setiap situasi, masingmasing merasa bahwa dirinya adalah untuk pasangannya. Disinilah inti redaksi wanita dan laki-laki yang keji adalah untuk pasangan sesamanya, begitu pula sebaliknya. Sehingga melahirkan fase keempat, terciptanya pemenuhan kebutuhan-kebutuhan pribadi secara utuh. ${ }^{16}$

Dari pemaparan di atas, dapat diketahui penafsiran surat an-nur ayat 26 dari berbagai sudut pandang ulama tafsir. Selanjutnya adalah kesesuaian tafsir dengan pengaplikasian-nya dalam film Ayat Tentang Cinta. Anwar memaknai surat an-Nur ayat 26 sebagai janji Allah untuk mempertemukan wanita yang baik pada laki-laki yang baik, membahas tentang bagaimana perempuan dan laki-laki harus memantaskan dirinya menjadi orang yang baik untuk mendapatkan pendamping hidup yang terbaik. Jika dilakukan komparasi terhadap pendapat ulama tafsir di atas, maka akan menimbulkan pemahaman yang melebar dengan interpretasi yang dilakukan Anwar terkait an-Nur ayat 26 pada poin pemantasan diri sebelum melaksanakan pernikahan. Akan tetapi secara substansi bahwa ayat ini merupakan janji Allah untuk mempertemukan laki-laki yang baik dengan perempuan yang baik memiliki kesamaan dengan penafsiran para ulama,

${ }^{15}$ M. Quraish Shihab, Tafsir Al-Misbah: Pesan, Kesan Dan Keserasian Al-Qur'an, 2002. 16 Ibid. 
walaupun tidak disebutkan secara eksplisit bahwa susunan redaksi dalam an-nur 26 merupakan janji, namun secara implisit redaksi tersebut dapat direpresentasikan sebagai sebuah janji Allah. Adapun terkait pemantasan diri adalah bagian dari proses yang dilalui untuk mencapai titik baik. Jalinan hubungan antar keduanya harus bermula dari adanya kesamaan antara kedua belah pihak (Quraish Shihab), bahkan dari suatu sumber menyebutkan bahwa surat an-nur 26 adalah salah satu landasan kafa'ah. ${ }^{17}$

Dapat disimpulkan film pendek Ayat Tentang Cinta memiliki relevansi yang erat dengan al-Qur'an sebagai produk tafsir, lebih dari itu film ini juga mengimplementasikan salah satu hukum Islam tentang kafa'ah atau kesepadanan yang merupakan implementasi dari sebuah hadis Nabi. Walaupun tercapainya tujuan pernikahan memang tidak mutlak ditentukan oleh kesepadanan semata, tetapi hal tersebut dapat menjadi penunjang yang utama, apalagi dalam hal agama dan akhlak yang baik. ${ }^{18}$ Argumentasi ini sesuai dengan adegan yang diperankan Anwar di akhir alur film. Bahkan jika ditinjau dari sudut pandang penjelasan Haydar terkait ayat tentang cinta, baginya tidak ada satu ayat al-Qur'an pun yang tidak menunjukkan cinta Allah kepada makhluk-Nya. Dari dialog yang dilontarkan Haydar tersebut seakan semakin membuat penonton hidup dengan nuansa dan rasa al-Qur'an yang ditransfer melalui film. Demikian dapat disimpulkan bahwa akses umat terhadap al-Qur'an maupun hadis selalu terbuka sepanjang masa ${ }^{19}$ melalui perantara apa saja.

\section{E. Nilai-nilai al-Qur'an dan Hadis dalam Film Ayat tentang Cinta sebagai Konstruksi Kesalehan}

Tradisi yang telah berlangsung berasal dari adanya habitualisasi secara kontinyu yang diwariskan ke generasi setelahnya dengan bahasa sebagai perantara. Disinilah terdapat peranan dalam suatu tatanan kelembagaan, termasuk juga berkaitan dengan pentradisian pengalaman tersebut. Jadi, pengaktualan peranan merupakan representasi diri sendiri. Peranan merepresentasikan keseluruhan rangkaian perilaku yang melembaga ${ }^{20}$, dalam

17 Syarifah Gustiawati and Novia Lestari, "Aktualisasi Konsep Kafa'ah Dalam Membangun Keharmonisan Rumah Tangga," Mizan 4, no. 1 (2016): 33-86.

${ }^{18}$ Shihab, Tafsir Al-Misbah: Pesan, Kesan Dan Keserasian Al-Qur'an.

${ }^{19}$ Nadirsyah Hosen, Tafsir Al-Qur'an Di Medsos, 2017.

${ }^{20}$ Aimie Sulaiman, "Memahami Teori Konstruksi Sosial Peter L. Berger," Society 4, no. 1 (2016): 15-22, doi:10.33019/society.v4i1.32. 
kasus kajian ini adalah peranan para tokoh dalam sektor film yang mengkonstruksi representasi kesalehan. Produksi film Ayat Tentang Cinta melakukan tahapan tersebut dari proses penyiapan materi, penyebarluasan melalui media film yaitu YouTube dan pembentukan konstruksi bagi audien yang menontonnya. Berger berpendapat bahwa setiap realitas dibentuk dan dikonstruksi, sehingga setiap orang dapat memiliki konstruksi yang bermacammacam atas suatu realitas berdasarkan pengalaman, preferensi, pendidikan tertentu dan lingkungan pergaulan atau sosial tertentu. Maka, dari adanya ragam latar belakang tersebut akan melahirkan realitas sosial dengan konstruksiya masing-masing. ${ }^{21}$

Nilai-nilai al-Qur'an dan Hadis Nabi dalam film Ayat tentang Cinta dapat dipahami melalui beberapa adegan, antara lain: pertama, adegan pembacaan ayat suci al-Qur'an oleh Anwar. Adegan tersebut memperlihatkan Anwar yang sedang melantunkan ayat suci al-Qur'an surat an-Nur: 26. Dalam hal ini, al-Qur'an merupakan ikon agama Islam karena dipahami oleh seluruh umat beragama sebagai kitab suci umat Islam. Maka, al-Qur'an itu sendirilah yang mengilustrasikan ikon dalam adegan tersebut. Sedangkan indeks dalam adegan ini muncul dari suara Anwar langsung yang sedang membacakan ayat al-Qur'an. Ini menunjukkan kehadiran nyata dari al-Qur'an sebagai ikon agama Islam yang berhubungan erat dengan audio yang bersumber dari suara Anwar.

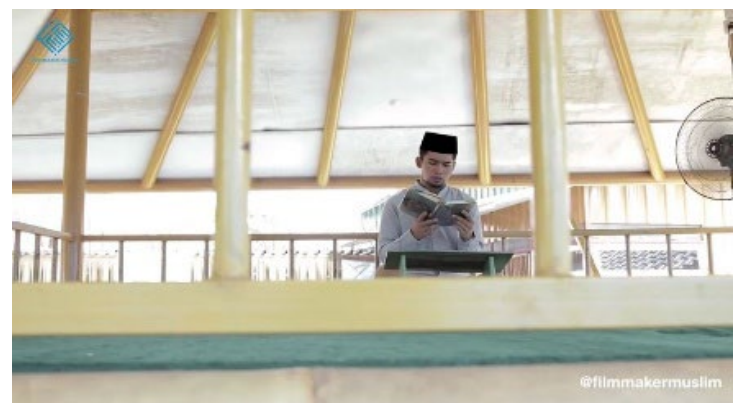

Gambar 1 (00: 37- 01: 24) 22

${ }^{21}$ Nurbayati, Husnan Nurjuman, and Sri Mustika, "Konstruksi Media Tentang Aspek Kemanusiaan Pada Poligami: Analisi Isi Terhadap Film Surga Yang Tak Dirindukan," Jurnal Riset Komunikasi 8, no. 2 (2017): 103-24. Lihat juga, Ana Zahida, "SURGA YANG TAK DIRINDUKAN : WACANA POLIGAMI DALAM FILM ISLAMI," n.d., 17-34.

${ }^{22}$ Amrul Ummami, Ayat Tentang Cinta, 2019. 
Makna indeksional dari scene ini dicitrakan oleh Anwar sebagai laki-laki yang baik; disebutkan dalam QS. an-Nur 26, adalah seseorang yang bisa membaca al-Qur'an dengan baik dan benar. Maka hal ini sekaligus merupakan representasi praktik dari potongan QS. al-Muzammil ayat 4 yang memiliki arti, Dan bacalah alQur'an itu dengan perlahan-lahan. Adapun makna simbolik merupakan tanda yang bersifat mewakili sesuatu 23. Kopiah hitam yang dikenakan Anwar merupakan simbol islami yang paling mencolok dari adegan ini. Dalam tradisi masyarakat Indonesia, laki-laki yang memakai kopiah secara spontan diidentifikasi sebagai penganut agama Islam. Selain itu, simbol islami juga tergambar dari latar pengambilan adegan yaitu sebuah surau kecil. Surau melambangkan tempat beribadah bagi umat Islam seperti halnya masjid dan mushola.

Kedua, permintaan restu orang tua untuk melamar. Adegan ini menunjukkan bakti seorang anak kepada kedua orangtuanya dengan meminta izin dan doa restu atas niat baiknya yang akan disampaikan pada keluarga seorang wanita yang ingin dilamarnya. Maka dapat dikatakan bahwa ikon dalam adegan ini terletak pada kata kunci berbakti. Hal ini ditunjukkan dari dialog yang terjadi antara Anwar dengan Abi dan Uminya. Anwar menyatakan kesiapan pada Abinya, adegan ini merupakan representasi praktik sebuah hadis Nabi tentang anjuran menikah; dengan bersatunya nanti kelaarga permepuan dan laki-laki, maka akan memperluas hubungan persaudaraan yang ada diantara keduanya. Hal ini dijelaskan dalam potongan surat al-Hujurat ayat 13.

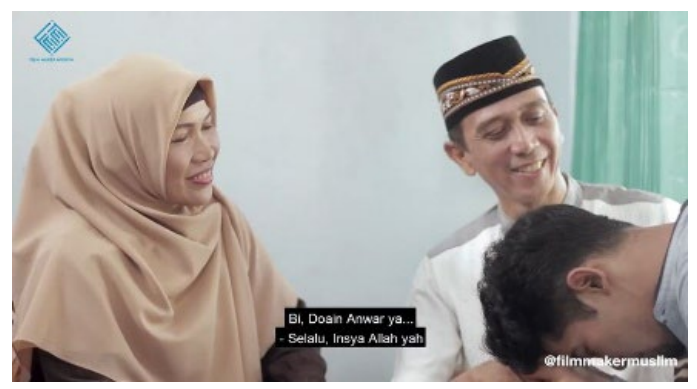

Gambar 2 (01: 31- 02: 40) ${ }^{24}$

23 Ubaidillah Ubaidillah, Ening Herniti, and Aning Ayu Kusumawati, "Pencitraan Perempuan Islami Dalam Iklan Komersial (Analisis Semiotika)," Musãwa Jurnal Studi Gender Dan Islam 16, no. 1 (2018): 1, doi:10.14421/musawa.2017.161.1-17.

24 Ummami, Ayat Tentang Cinta. 
Ikon di atas melahirkan hubungan yang erat dengan makna indeks berupa adanya sikap saling menghormati dan menghargai antara anak dan orangtua. Hal tersebut tercermin dari dialog selanjutnya yang dilontarkan Umi Anwar pada anaknya berupa tawaran kedua orangtua untuk turut serta menemani Anwar yang hendak melamar gadis pilihannya. Akan tetapi Anwar menolak halus tawaran tersebut dengan alasan bahwa proses tersebut masih sekedar penyampaian niat baik untuk melamar, artinya jika sudah diperkenankan oleh pihak wanita, maka dengan senang hati Anwar akan mengikut sertakan kedua orangtuanya, dan mereka pun menghormati keputusan Anwar tersebut dengan tidak memaksakan kehendak. Makna simbolik dari permintaan dan pemberian ridha antara mereka terjadi pada adegan Anwar mencium tangan Abi dan Uminya dengan penuh rasa ta'zhim. Scene ini pun merupakan representasi praktik dari hadis Nabi yang menjelaskan bahwa keridaan Allah tergantug pada keridaan orang tua.

Ketiga, pencitraan sosok Fatimah. Suara narator Anwar mendiskripsikan bagaimana sosok gadis idamannya, Fatimah az-Zahra. Bagian ini disertai dengan adegan-adegan yang diperankan oleh Fatimah dan menunjukkan kesalehan yang melekat pada dirinya. Ikon kesalehan adalah tanda yang paling dominan dalam adegan ini, dimana seluruh tindakan yang dilakukan Fatimah menggambarkan sesosok wanita salehah. Indeks yang menunjukkan ikon kesalehan direpresentasikan dari akhlak mulia Fatimah yang diimplementasikan melalui beberapa adegan, antara lain merapikan alas kaki jamaah sebelum masuk ke masijd, mendirikan salat, membaca al-Qur'an dan mempelajari kitab hadis. Sedangkan simbol yang mencerminkan kesalehan sosok Fatimah dapat dilihat dari pakaian yang dia kenakan. Mulai dari jilbab lebar, gamis panjang sampai kaos kaki, yang semua itu pada zaman sekarang sering disebut-sebut dengan istilah pakaian syar'i.

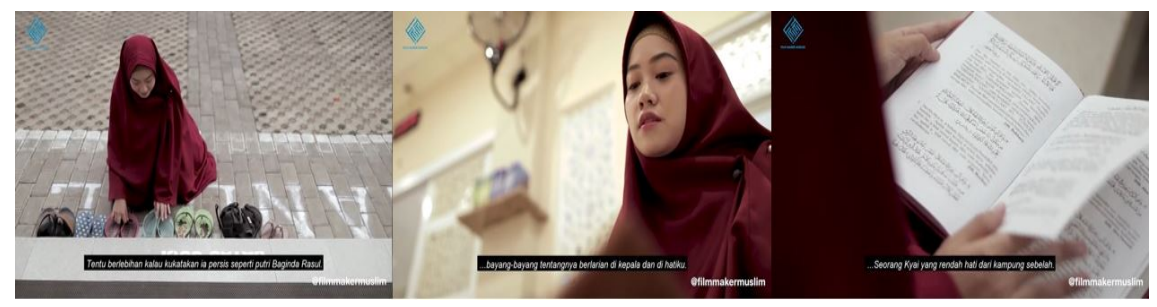




\section{Gambar 3 (03: 29- 04: 29) ${ }^{25}$}

Menurut Afifah, tanpa disadari wacana-wacana tentang pakaian syar'i yang tersebar melalui media sosial secara tidak langsung menghegemoni busanabusana lain yang dianggap tidak syar'i ${ }^{26}$. Istilah yang muncul belakangan ini terlahir dari adanya dogma sosial yang menganggap pakaian syar'i adalah pakaian yang sesuai dengan syariat agama Islam yang diilustrasikan oleh media sehingga menjadi tren busana dalam kehidupan nyata. Sehingga, katakanlah busana muslim yang cenderung tidak panjang dan lebar bukan termasuk dalam kriteria pakaian syar'i. Padahal kaca syar'i sendiri berasal dari tradisi budaya berpakaian orang-orang Arab yang telah mengalami metamorfosis dari dulu hingga sekarang dan hasil metamorfosisnya ditiru oleh orang-orang non-Arab termasuk masyarakat Indonesia.

FMM, dalam konteks ini, eksistensinya muncul di tengah hegemoni yang terjadi, secara langsung maupun tidak langsung pun turut berperan sebagai pengkonstruk sosial masyarakat, khususnya yang beragama Islam. Oleh karena itu, salah satu cara FMM membangun opini publik atas kesalehan pemeranpemeran filmnya adalah dengan memilih kostum yang merefleksikan ke-syar'ian dan tentunya lumrah dikenal oleh masyarakat dengan kriteria-kriteria pakaian yang sudah disebutkan sebelumnya.

Keempat, pertemuan pertama Anwar dan Haydar dengan keluarga Fatimah. Adegan ini menggambarkan respon Abah Fatimah terhadap anaknya dan dua laki-laki yang sama-sama berkeinginan memperistri Fatimah. Ikon pada adegan ini diwakilkan oleh Abah Fatimah yang memiliki sikap moderat. Selanjutnya, sikap moderat tersebut dinyatakan dalam dua tindakan yang memiliki relasi indeksional yaitu dengan memberikan tawaran mutlak pada anaknya untuk memilih Anwar atau Haydar sebagai calon suaminya dan memberikan persyaratan yang adil kepada keduanya sesuai dengan kapabilitas yang sama-sama dimiliki Anwar maupun Haydar. Adegan-adegan yang mengisyaratkan sikap moderat Abah Fatimah disimbolkan dengan adanya kemufakatan antara pihak yang bersangkutan, baik dari Anwar, Haydar, maupun Fatimah.

${ }^{25}$ Ibid.

26 Nurul Afifah, “Pakaian Syar'I, Media Dan Konstruksi Kesalehan Perempuan,” Jurnal Sosiologi Reflektif 13, no. 1 (2019): 61, doi:10.14421/jsr.v13i1.1544. 


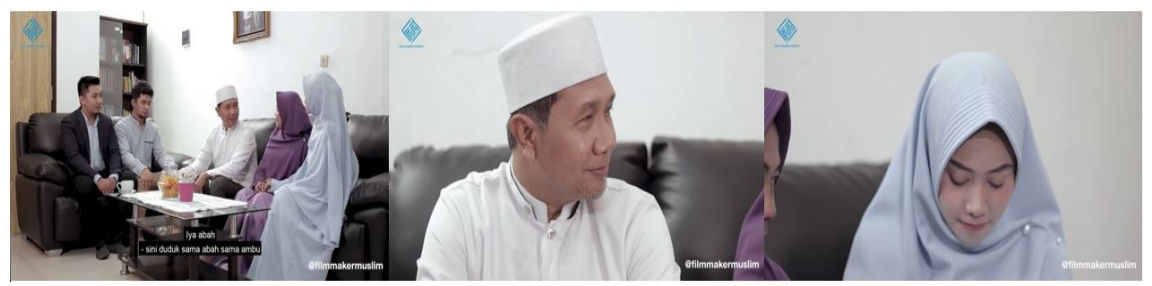

Gambar 4 (09: 21- 10: 55)

Lebih jauh dari pada itu, al-Qur'an kembali menjadi ikon pada bagian ini saat Abah Fatimah bertanya, "Nak Anwar dan Nak Haydar bisa baca al-Qur'an?". Setelah mengetahui bahwa keduanya bisa membaca al-Qur'an, Abah Fatimah melanjutkan syaratnya supaya mereka berdua mencari ayat cinta dalam alQur'an dan menjelaskannya satu minggu kemudian agar Fatimah paham maksud dari kata cinta. Dengan begitu, adegan ini sangat mengedepankan nilai al-Qur'an dan secara tidak langsung bisa dikatakan sebagai refleksi hadis nabi tentang keutamaan belajar dan mengajarkan al-Qur'an. Pada bagian ini terdapat beberapa rentetan adegan yang membentuk konstruksi kesalehan, diantaranya ketika Fatimah menyerahkan keputusan memilih laki-laki yang tepat kepada kedua orangtuanya atas dalih belum pernah merasakan jatuh cinta. Sikap tersebut mencerminkan bakti anak pada orang tua dan bernilai ibadah. Selain itu, konstruksi kesalehan juga terletak pada adegan ketika Anwar dan Haydar menyanggupi syarat yang diajukan oleh Abah Fatimah. Dengan kata lain, mereka siap mencari ridha Allah dengan berusaha memenuhi syarat yang tidak keluar dari ajaran agama, bahkan mengandung nilai keagamaan yang sangat kuat.

Kelima, pencitraan Anwar sebagai orang yang berilmu. Sebelum sampai pada scene di atas, pembahasan ini didukung oleh narasi Anwar yang berbunyi, “27 tahun belajar agama, mendalami al-Qur'an dan terjemahannya, menyantap buku tafsir dan keilmuan Islam, baru kali ini pertanyaan tersebut muncul dan menjadi penting. Fatimah, semoga Allah meridhoiku mengajarimu tentang cinta." Melalui narasi tersebut, opini publik telah terbangun bahwa Anwar adalah seorang laki-laki saleh dan memiliki kelimuan agama yang luas. Redaksi yang menyusun opini publik tersebut sekaligus merupakan ikon dari adegan ini. Makna indeksional yang mendukung keilmuannya berasal dari kesatuan adegan

27 Ummami, Ayat Tentang Cinta. 
dimana Anwar setiap hari tidak pernah berputus asa mencari ayat cinta dengan mengkaji al-Qur'an bersama orang tua dan rekan-rekannya. Sedangkan makna indeksional pendukung kesalehan Anwar terletak pada adegan mendirikan shalat berjamaah dan mengadakan majelis ta'lim di masjid. Sehingga dapat ditarik benang merah, bahwa makna simboliknya adalah rumpun kepribadian Anwar berupa laki-laki yang giat dan pantang menyerah.

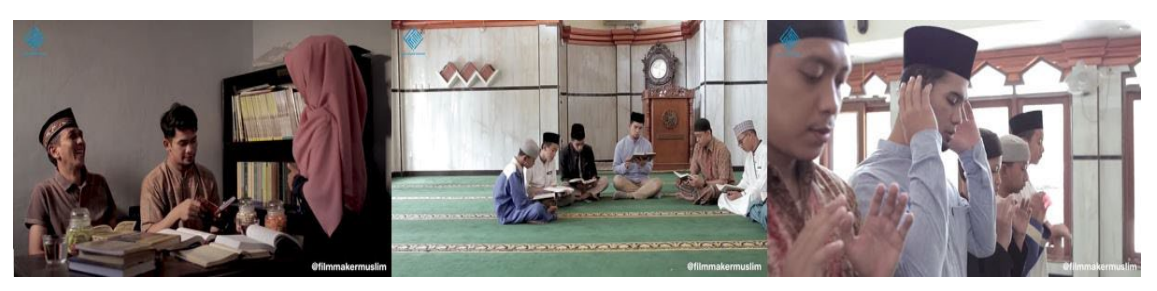

Gambar 5 (11: 57- 12: 45) ${ }^{28}$

Keenam, pertemuan kedua Anwar dan Haydar dengan keluarga Fatimah. Bagian ini terbagi menjadi dua pembahasan inti adegan. Adegan pertama terjadi saat Anwar menjelaskan ayat tentang cinta, disusul oleh adegan kedua berupa penjelasan ayat tentang cinta dari Haydar. Ikon seorang Anwar digambarkan sebagai sosok yang over confidence (terlalu percaya diri). Bukti indeksional yang menunjukkan sikap ini dapat dijajak dari beberapa adegan dan dialog yang diperankan oleh Anwar, diantaranya ketika Anwar mengajukan diri untuk terlebih dulu mempresentasikan ayat tentang cinta. Disini seolah mengisyaratkan Anwar ingin terlihat lebih unggul dari Haydar. Selain itu juga terletak pada dialog, "Sebelumnya Abah meminta saya eh kami untuk memberikan ayat tentang cinta..." seraya melirik ke arah Haydar. Redaksi tersebut mencerminkan sikap sombong dari diri Anwar yang merupakan buah dari adanya sifat terlalu percaya diri. Adegan lain ditunjukkan ketika Anwar menunjuk dirinya sebagai laki-laki yang baik dengan meletakkan tangan ke dadanya saat menjelaskan QS. an-Nur: 26 dalam satu kesatuan dialog yang berbunyi "Tentang janji Allah untuk mempertemukan wanita yang baik pada laki-lakiyang baik...", hal ini secara jelas memiliki keterkaitan dengan sosok Anwar yang diikonkan sebagai laki-laki yang terlalu percaya diri. Beberapa poin tersebut dapat disimbolkan

28 Ibid.

JURNAL THEOLOGIA — Volume 31, Nomor 1, Juni 2020 
melalui gerak-gerik, nada bicara dan mimik muka Anwar yang menampakkan kemantapan sekaligus keyakinan penuh dalam kontestasi merebut hati Fatimah.

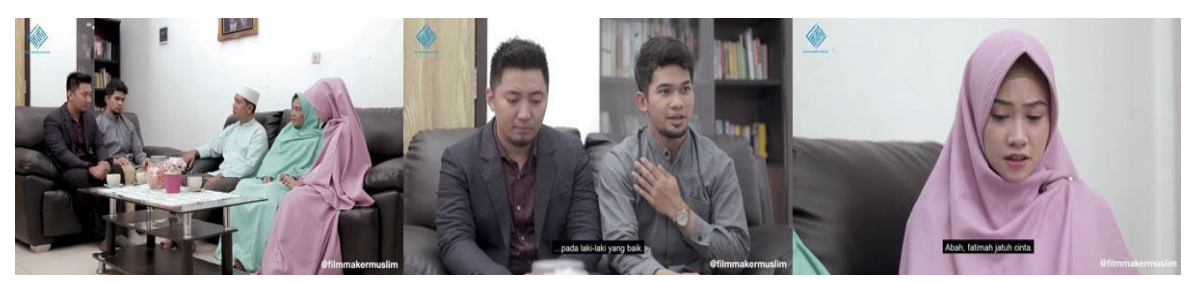

Gambar 6 (12: 56- 16: 30) ${ }^{29}$

Adapun ikon yang merepresentasikan Haydar adalah seorang laki-laki yang tawadhu' atau rendah hati. Makna indeksional yang mendukung figur tersebut ditandai dari pertama kali Haydar membuka pembicaraan. Permohonan maaf diungkapkan karena Haydar tak kunjung menemukan ayat tentang cinta. Menurut pengakuannya, tidak ada satu pun ayat al-Qur'an yang tidak membuktikan cinta pada makhluk-Nya. Penjelasan Haydar secara tidak langsung merupakan refleksi komprehensif dari surat al-Kahf ayat 109 yang artinya, Katakanlah: Sekiranya lautan menjadi tinta untuk (menulis) kalimat-kalimat Tuhanku, sungguh habislah lautan itu sebelum habis (ditulis) kalimat-kalimat Tuhanku, meskipun Kami datangkan tambahan sebanyak itu (pula)". Selanjutnya terletak pada dialog Haydar yang berbunyi, "Kalau syarat meminang Fatimah adalah membuktikan satu ayat tentang cinta Allah pada makhluk-Nya, saya minta maaf mungkin saya belum mampu dan belum pantas". Melaui dialog, Haydar benar-benar mengungkapkan kondisi yang ada pada dirinya dengan apa adanya, tanpa ada rasa Haydar ingin mengungguli Anwar untuk mendapatkan Fatimah, dia siap dengan segala keputusan yang terjadi, termasuk jika Fatimah tidak memilihnya. Sehingga rentetan sikap yang mencerminkan kerendah-hatian Haydar disimbolkan dari adegan yang berisi kelembutan dan sopan santun yang disuguhkan Haydar pada keluarga Fatimah. Konstruksi kesalehan lain yang mendukung adegan film ini terletak ketika Fatimah menjatuhkan pilihannya pada Haydar, bukan pada Anwar. Memang keilmuan agama yang dimiliki Anwar penting dipertimbankan, akan tetapi akhlak terpuji yang dimiliki Haydar menjadi

29 Ibid. 
lebih penting karena dalam konteks film ini Fatimah dihadapkan pada dua lakilaki yang sama-sama berpendidikan.

Ketujuh, pencitraan sosok Haydar. Pada adegan terakhir, pencitraan Haydar dinarasikan langsung oleh Anwar dalam kalimat:

Namanya Haydar, laki-laki dengan keseimbangan akhlak dan ilmu, jauh dari kesombongan, bersahabat dengan kerendah hatian. Aku pernah sombong dengan berfikir bahwa diriku layak bersanding dengan Fatimah. Bahwa semua hafalanku, semua ibadahku, semua kebaikan yang pernah kulakukan, membuatku pantas bersanding dengannya. Kemudian kupandang Haydar, dan dengan penuh kesombongan. Kunilai dia dari penampilannya yang tidak menonjokan keilmuan apapun tentang agama. Dari Fatimah dan Haydar aku belajar menjadikan ilmu sebagai alasan untuk rendah hati, menjadikan akhlak sebagai satu-satunya penghias diri. Dari keduanya akupun belajar mencintai dengan ikhlas takkan meninggalkan luka. Sebaliknya, patah hatinya akan mendekatkan kita kepada sang pencipta. ${ }^{30}$

Narasi tersebut menyingkap dengan sangatjelas tentang seluruh kebaikan yang terpatri dalam diri Haydar. Walaupun dia tidak memiliki peran banyak dalam adegan film dan cenderung pasif dalam pembagian peran, namun tidak menjadikannya tenggelam atas pemeran lain yang pro-aktif di setiap adegan. Analisis adegan terakhir inilah yang berhubungan erat dengan gambar 6 tentang penggambaran kendaraan yang dimiliki oleh Anwar dan Haydar. Bahwa tingginya status sosial ataupun status keilmuan seseorang tidak bisa dijadikan barometer kebaikan seseorang tanpa disertai dengan budi pekerti yang baik. Seorang Haydar yang secara penampilan menggambarkan kelas sosial yang lebih tinggi dibanding Anwar tidak bisa bebas diklaim sebagai orang yang memiliki pengetahuan dan akhlak yang rendah. Pun sebaliknya, seorang Anwar yang menggambarkan kesederhanaan dan memiliki keilmuan keagamaan tidak bisa dipandang sebagai orang yang berkelas sosial rendah. Pengembangan narasi Anwar menunjukkan penerapan pendidikan spiritual ${ }^{31}$ dalam suatu film melalui improvisasi karakter Anwar.

${ }^{30}$ Ibid.

31 Wiruma Titian Adi and Andika Hendra Mustaqim, "PENGEMBANGAN NARASI FILM 99 CAHAYA DI LANGIT EROPA UNTUK PENDIDIKAN SPIRITUAL," Leksema 2, no. 2 (2017): 145-59.

JURNAL THEOLOGIA — Volume 31, Nomor 1, Juni 2020 


\section{F. Penutup}

Dua pertanyaan inti dalam kajian ini, yaitu: pertama, bagaimana film Ayat tentang Cinta memosisikan al-Qur'an [dan hadis] hingga ia tanpa sebagai representasi dari sebuah tafsir dan syarah? Kedua, bagaimana pula keberadaan nilai-nila al-Qur'an [dan hadis] dalam film tersebut menjadi salah satu konstruk dari kesalehan? Terjawab dengan dua narasi penting, pertama, pada dasarnya, tafsir terhadap al-Qur'an dan syarah terhadap hadis Nabi bisa terus berkembang seiring dengan perkembangan zaman. Tafsir al-Qur'an dan syarah hadis tidak hanya terbatas pada tulisan-tulisan berjilih-jilid; melainkan bisa terus bermetamorfosis dan menyesuaikan dengan media-media baru seperti internet dan lainnya. Media-media baru tersebut bisa berupa film-film religi dan sebagainya.

Pada contoh kasus film Ayattentang Cinta, tampakjelas bagaimana adegan yang ditampilkan di dalamnya mampu menunjukkan titik relevansi sebuah film sebagai tafsir dan syarah, misalnya tentang kualitas pasangan dan kafaah. Kedua, film-film religi bisa menjadi media penting dalam mentransfomrasikan nilai-nilai al-Qur'an dan hadis. Pada film Ayat tentang Cinta, banyak ditemui nilai-nilai dari dua teks suci ini dalam bentuknyayang beragam, baikyang bersifatumum seperti penampakan simbol-simbol agama, maupun yang memang spesifik seperti bagaimana masing-masing tokoh sentral dalam film tersebut menjelaskan hal-hal relevan dengan nilai al-Qur'an dan hadis melalui adegan-adegan yang khas. Semua ini, sekaligus menjadi salah satu fakta menarik akan adanya upaya konstruksi kesalehan dalam benak audien.

\section{DAFTAR PUSTAKA}

Adi, Wiruma Titian, and Andika Hendra Mustaqim. "PENGEMBANGAN NARASI FILM 99 CAHAYA DI LANGIT EROPA UNTUK PENDIDIKAN SPIRITUAL." Leksema 2, no. 2 (2017): 145-59.

Afifah, Nurul. "Pakaian Syar'I, Media Dan Konstruksi Kesalehan Perempuan." Jurnal Sosiologi Reflektif13, no. 1 (2019): 61. doi:10.14421/jsr.v13i1.1544. Al-Mahalli, Jalaluddin, and Jalaluddin As-Suyuthi. Tafsir Jalalain; Lengkap Dan Disertai Asbabun Nuzul, 2017. 
Basri, Syaiful Qadar. "Film 99 Cahaya Di Langit Eropa Yang Merepresentasikan Film As Social Practice Bagi Wanita Muslimah." Studi Islam 15 (2019): 5874.

Fatimah, Nur. "MEMBINGKAI AJARAN ISLAM DENGAN PRODUK MULTIMEDIA HAKIKAT KAYA DALAM FILM DOKUMENTER RELIGI 'BUKAN SEPERTI MISKIN TIDAK SEPERTI KAYA." JURNAL ILMU DAKWAH36, no. 2 (2016): 211-28.

Gustiawati, Syarifah, and Novia Lestari. "Aktualisasi Konsep Kafa'ah Dalam Membangun Keharmonisan Rumah Tangga." Mizan 4, no. 1 (2016): 3386.

Hamdan, Ali, and Miski. "Dimensi Sosial Dalam Wacana Tafsir Audiovisual." Religia 22, no. 2 (2019): 248-66.

Hariyadi. "Finding Islam in Cinema: Islamic Films and the Identity of Indonesian Muslim Youths." Al-Jami'ah: Journal of Islamic Studies 51, no. 2 (2013): 443-73. doi:10.14421/ajis.2013.512.443-473.

Hosen, Nadirsyah. Tafsir Al-Qur'an Di Medsos, 2017.

Ishaq, Ropingi el. "HIBURAN DAN DAKWAH: SEBUAH ERA BARU DAKWAH ISLAMIYAH." AT-TABSYIR 2, no. 1 (2014): 117-32.

"ISLAMIC FILMS AND IDENTITY: THE CASE OF INDONESIAN MUSLIM YOUTHS," n.d.

Jalaluddin, and Nabilla Putri Syarifa. "Represenasi Citra Positif Islam Dalam Film Kingdom of Heaven." LP3M 4 (2018): 122-31.

Lilis, Alga, Kusuma Dewi, Muhammad Zamroni, Soekma Yeni Astuti, Fakultas Ilmu Budaya, and Universitas Jember. "Analisis Semiotika Film Christian Metz: Studi Kasus Visualisasi Pesan." PUBLIKA BUDAYA 5, no. 1 (2017): 21-27.

Miski. “Fenomena Meme Hadis Celana Cingkrang Dalam Media Sosial." Harmoni 16, no. 2 (2017): 291-306.

- "Komikisasi Hadis: Arah Baru Syarah Hadis Di Indonesia Studi Kritis Atas 99 Pesan Nabi: Komik Hadis Bukhari-Muslim." Millati: Journal of Islamic Studies and Humanities 2, no. 1 (2017): 125-44. doi:10.18326/mlt.v2i1.125-144.

Mudin, Miski. ISLAM VIRTUAL, Diskursus Hadis, Otoritas, Dan Dinamika Keislaman 
Di Media Sosial. Edited by Nurul Afifah. 1sted. Yogyakarta: BILDUNG, 2019. Musyafak, M Ali. "FILM RELIGI SEBAGAI MEDIA DAKWAH ISLAM." JURNAL ISLAMIC REVIEW II, no. 2 (2013): 327-38.

Nafisatuzzahro'. "Tafsir Al-Qur'an Audiovisual Di Cybermedia: Kajian Terhadap Kajian Al-Qur'an Di Youtube Dan Implikasinya Terhadap Studi Al-Qur'an Dan Tafsir." UIN Sunan Kalijaga, 2016.

Nisa, Masturina Khoirun, Ucik Ana Fardila, and Agus Widodo. "ISI PESAN DAKWAH AQIDAH DAN SYARIAH DALAM FILM INDONESIA ISLAMI 'JILBAB TRAVELER LOVE SPARKS IN KOREA' (Kajian Semiotik Pada Film Islami Indonesia)." TRANSLITERA 8 (2019): 1-12.

Nurazizah, Tika Kania, Saeful Anwar, and Bahrudin Bahrudin. "Pesan Dakwah Pada Media Sosial." Tabligh: Jurnal Komunikasi Dan Penyiaran Islam 3, no. 3 (2020): 275-91. doi:10.15575/tabligh.v3i3.699.

Nurbayati, Husnan Nurjuman, and Sri Mustika. "Konstruksi Media Tentang Aspek Kemanusiaan Pada Poligami: Analisi Isi Terhadap Film Surga Yang Tak Dirindukan." Jurnal Riset Komunikasi 8, no. 2 (2017): 103-24.

Putra, Robby Aditya. "Dampak Film Para Pencari Tuhan Jilid X Terhadap Religiusitas Remaja." Jurnal Dakwah Dan Komunikasi 3, no. 1 (2018): 1-24.

Rahtikawati, Yayan, and Dadan Rusmana. Metodologi Tafsir Al-Qur'an, 2013.

Rohimi, Primi. “Keragaman Islam Dalam Film Indonesia.” Jurnal Dakwah 16, no. 2 (2015): 291-304.

Sa'idah, Zahrotus. "Konstruksi Kesalehan Dalam Film Cinta Suci Zahrana (Antara Identitas, Modernitas Dan Komodifikasi Agama)." Thesis (2017): 1-112.

Shihab, M. Quraish. Tafsir Al-Misbah: Pesan, Kesan Dan Keserasian Al-Qur'an, 2002.

Sulaiman, Aimie. "Memahami Teori Konstruksi Sosial Peter L. Berger." Society 4, no. 1 (2016): 15-22. doi:10.33019/society.v4i1.32.

Syah, Hakim. “DAKWAH DALAM FILM ISLAM DI INDONESIA ( Antara Idealisme Dakwah Dan Komodifikasi Agama )” XIV, no. 2 (2013): 263-82.

Toni, Ahmad, and Rafki Fachrizal. "Studi Semitoka Pierce Pada Film Dokumenter The Look of Silence: Senyap.” Jurnal Komunikasi 11, no. 2 (2017): 137-54. doi:10.20885/komunikasi.vol11.iss2.art3. 
Ubaidillah, Ubaidillah, Ening Herniti, and Aning Ayu Kusumawati. "Pencitraan Perempuan Islami Dalam Iklan Komersial (Analisis Semiotika)." Musãwa Jurnal Studi Gender Dan Islam 16, no. 1 (2018): 1. doi:10.14421/musawa.2017.161.1-17.

Ummami, Amrul. Ayat Tentang Cinta, 2019.

Wahjuwibowo, and Indawan Seto. Semiotika Komunikasi Edisi III: Aplikasi Praktis Untuk Penelitian Dan Skripsi Komunikasi, 2019.

Wahyuda, Muhammad. "PERAN FILM AYAT-AYAT CINTA 2 TERHADAP PRILAKU ETIKA ISLAM PADA REMAJA." Syifa Al-Qulub 22 (2018): 31-40.

Zahid, Moh. "POSISI DAN FUNGSI MUSHHAF AL-QUR'AN DALAM KOMUNIKASI MASSA." Nuansa 11, no. 1 (2014): 77-106.

Zahida, Ana. "SURGA YANG TAK DIRINDUKAN: WACANA POLIGAMI DALAM FILM ISLAMI," n.d., 17-34.

Zuhri, Saifuddin, Moh Hidayat Noor, and Miski. "Komunitas Online Www.arrahmah.com Serta Seruan Kembali Pada Al-Quran Dan Hadis: Identitas, Ideologi, Dan Imaji Fundamentalisme." In Ancoms: 2nd Annual Conference for Muslim Sholars, 144-60, 2018. 
MilA AULIA, MisKI: Film Islami Sebagai Model Interpretasi... 